\title{
Analysis of Participation of Micro, Small, and Medium Enterprises (MSMEs) Taxpayers in Utilizing Tax Incentives Affected by the COVID-19 Pandemic
}

\author{
Imam Agus Faisol a ${ }^{\text {iD }}$, Tito IM. Rahman Hakim a 1 iD
}

${ }^{a}$ Trunojoyo University, Madura, Indonesia

\section{APA Citation:}

Faisol, A.F., \& Hakim, R.T. (2021). Analysis of the participation of micro, small, and medium enterprises (MSMEs) taxpayers in utilizing tax incentives affected by the covid-19 pandemic. TIJAB (The International Journal of Applied Business), 5(1), 71-80.

Submission Date: 15/02/2021

Acceptance Date: 14/04/2021

\begin{abstract}
This study aims to assess the effectiveness of COVID-19 tax incentives, issued by Indonesian government, which focused on micro, small, and medium enterprises (MSMEs) taxpayers who participate in the tax incentives. Using a qualitative method, this study used in-depth interviews with 2 informants who were a tax consultant and a smallmedium enterprise accountant. The findings show that the effectiveness of the COVID-19 tax incentive is still lacking, and it is in line with the participation of MSMEs that is still at a low level in utilizing tax incentives. The low participation of MSMEs in utilizing tax incentives can be seen from the data, which shows that after 5 months of running the program, only 200,000 out of around 2.3 million MSMEs who have taken the advantage of using this facility. The tax consultant states that the scheme that has been implemented in mitigating the financial burden of MSMEs is not effective for the non-substantial incentives object. The informant also suggests that the incentives should be given to cover value-added tax. The government is expected to create a new and better incentive scheme. The new incentive scheme is needed to provide a balanced responsibility to both government and society. This paper contributes theoretically by examining new types of tax incentives, namely COVID-19 tax incentives, and hopefully will help policymakers in making the better tax incentive schemes in the future.
\end{abstract}

Keywords: COVID-19; tax incentive; MSMEs

This is an open access article under the $\underline{C C B Y-N C \text {-SA license. }}$

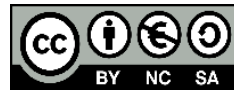

\section{Introduction}

COVID-19 is a pandemic that attacks the world globally. Indonesia is one of the countries affected by COVID-19 and has suffered considerable losses due to its unpreparedness in facing this pandemic. Many sectors have been affected by this pandemic, especially the economy sector. Many companies and MSMEs have to go bankrupt because of the prohibition to carry out work-related activities which resulting on many layoffs and lower purchasing power. The OECD (2020) states that the government should take mitigation movement by providing subsidies or other ways, which will be impactful for

\footnotetext{
${ }^{1}$ Corresponding author.

E-mail address: tito.rhakim@trunojoyo.ac.id
} 
reducing economic output for quite some time. The subsidy can be in the form of tax incentives for business people so that the losses suffered are not too heavy, and both companies and MSMEs can continue to operate and maintain their employees.

Indonesia follows the OECD's call (2020) to participate in implementing policies for reducing the massive negative impact of COVID-19. By looking at that fact, the writers wrote this paper to examine the level of participation and effectiveness of one of Indonesia's economic policies during the COVID19 pandemic, particularly in the tax sector. This policy's effectiveness is studied by conducting in-depth interviews with informants who were; a tax consultant and an accountant at companies that receive tax incentives. Regarding the tax incentives, MSME is an interesting sector to examine since it becomes the relatively centre of attention in the midst of a pandemic. Based on the MSMEs' measurement in 2018, the 64.19 million of Indonesia's business sector absorbed 97\% of the total workforce in Indonesia, which equals to 117 million workers (kompaspedia.kompas.ac.id). This information illustrates the government that the MSME sector needs to be a concern amidst the COVID-19 national disaster.

Through the Ministry of Finance and the Directorate General of Taxes, the government has responded to save the country's economic conditions. One of the government's responses is to provide a stimulus in tax incentives for taxpayers affected by the COVID-19 pandemic. The first tax incentive regulation to be issued was PMK-23/PMK.03/2020. One form of tax incentives in PMK 23, namely income tax 21 borne by the government for the manufacturing sector, is included in the 440 business field classifications and taxpayers who receive import facilities for export purposes. Exemption of income tax 22 on imports specifically for certain manufacturing sectors included in the 102 business field classifications and taxpayers who receive import facilities for export purposes. Moreover, there is a 30\% reduction in income tax 25 instalments and preliminary value-added tax refunds.

The government's response by issuing PMK 23 has not fully supported the MSME sector. The facilities stipulated in PMK 23 are still focused on favouring certain manufacturing sectors and taxpayers who obtain import facilities for export purposes. Following up on these conditions, the government issued a regulation accommodating taxation activities for the MSME sector. PMK-44/PMK.03/2020 is a government stimulus that provides tax incentives by expanding the scope of the tax facilities provided. The release of PMK-44 explains that the government is expanding the provision of tax incentives by involving MSME business people.

PMK-44 provides taxation stimulus to MSMEs in the form of MSME Final income tax incentives that the government bears. The enforcement of PMK-44 automatically makes PMK-23 invalid/revoked. Final MSME income tax incentives are given to taxpayers who have a business circulation below 4.8 billion and have previously used PP Number 23 of 2018 and to taxpayers who have a certificate based on PMK-44/PMK.03/2020. After that, the taxpayer needs to submit a report on the realization of Final income Tax borne by the government at a maximum of the 20th after the end of the tax period. Incentives are valid from April to September 2020.

The government has provided economic stimulus, one of which is tax incentives for business people. It is expected that with this stimulus, business people can survive and continue to carry out their business activities. MSMEs as taxpayers are one of the government's main targets to save the country's economy. MSMEs are expected to play an active role in utilizing this tax incentive. The government expects that MSMEs will continue to exist and that going concern will remain a real and realistic principle for dealing with this phenomenon. The synergy between the government and MSMEs needs to be well established to improve the sluggish economic conditions due to the COVID-19 pandemic.

The final income tax that the government bears can reduce the costs of MSME entrepreneurs. MSMEs can take advantage of these cost reductions to divert them to other productive activities. This research wants to capture and analyse taxpayers' participation in taking advantage of the COVID-19 tax 
incentives. Participation is viewed from the aspect of willingness to access incentive application letters and calculating and reporting the realization of the final income tax borne by the government.

Research related to tax incentives has been carried out quite a lot both by the OECD institutionally and by independent researchers. In general, there are several types of tax incentives that have been studied globally, namely R\&D tax incentives (Manly et al., 2006; OECD, 2010; Jose et al., 2020), investment tax incentives (OECD, 2000; Manly et al., 2006; Daude et al., 2017), tax incentives related to biodiversity conservation (Van Wyk, 2010), and tax incentives on mining (OECD, 2018). This study measures tax incentives' effectiveness in triggering certain aspects that have been determined when this incentive is implemented. Even though the effectiveness of these tax incentives is still questionable, many developing countries use this scheme to substitute the unprofitable business climate (OECD, 2008). This paper adopts the parameters of tax incentive effectiveness from Roca (2010). He measures the effectiveness of tax incentives from their benefits. The tax incentives would be effective if this could give taxpayers (MSMEs) some relief from their financial burden amidst the pandemic.

This paper shed a light on a new type of incentive that appears due to the pandemic at the end of 2019, namely tax incentives during the COVID-19 pandemic. The findings show that companies (MSMEs) are greatly helped by this incentive, although it is hoped that there are other tax incentive schemes that are more efficient for MSMEs. However, these incentives' effectiveness is still questionable due to the limited funds owned by the state. This research theoretically contributes in giving a fresh perspective related to the new tax incentives that were rarely studied previously. Moreover, the paper's findings provide an overview of the effectiveness of granting tax incentives to MSMEs by the Indonesian government.

The government can take the results of this research into consideration for developing more efficient incentive schemes. For the next sections, this paper is organized as follows; In the second part, a literature review explains the objects of tax incentives and the regulation of COVID-19 tax incentives used to support phenomena related to the discovery of perceptions and the effectiveness of COVID-19 tax incentives. The third part of the paper describes the research method and followed by the fourth section, which explains the research findings. The final section contains an explanation of the conclusions of this study.

\section{Literature Review}

\subsection{Final Income Tax for MSME Taxpayers}

The income tax that is final, in nature, for MSMEs is initially regulated in the Government Regulation of the Republic of Indonesia Number 46 of 2013, which is concerning income tax on income from businesses received or obtained by taxpayers who have certain tax circulation. In principle, the PP-46 regulates the income tax imposed on taxpayers with a gross turnover of below 4.8 billion in one year at a rate of $1 \%$ at final. However, in 2018 PP-46 was no longer valid due to a change in the final income tax rate from $1 \%$ to $0.5 \%$.

In June 2018, the government issued Government Regulation of the Republic of Indonesia Number 23 of 2018 which is concerning about the Income Tax from business income that is received or obtained by taxpayers who have a certain gross turnover. The enactment of the PP-23 indicates a reduction in the final tariff for MSMEs from $1 \%$ to $0.5 \%$. On the other hand, with the PP-23, not all taxpayers with a gross turnover of below 4.8 billion can get a $0.5 \%$ final income tax facility. Several taxpayers are exempted from PP-23, including experts who do independent work, consisting of lawyers, accountants, architects, doctors, consultants, notaries, PPATs, appraisers, and actuaries. Some taxpayers who have certain professions (music player, presenter, singer, comedian, film star, soap opera star, commercial 
star, director, film crew, model, drama player, dancer, sportsman, advisor, teacher, trainers, lecturers, extension agents, moderators, authors, researchers, translators, advertising agents, project supervisors/managers, intermediaries, merchandise hawkers, insurance agents and distributors of tiered marketing companies or direct sales and other similar activities) are also excluded, referring to PP 23.

There are several instruments for the change of PP-46 to PP-23 that apart from tariffs, including the addition of timeframe provisions, the right to vote to be subject to final income tax or not, adjustments to the criteria for corporate taxpayers, adjustment of subject exclusions subject to PP, confirmation of turnover for individual taxpayers of the status of separate assets and management, as well as additional methods of deposit. PP-23 regulates the maximum period of imposition, which are; 7 tax years for individual taxpayers, 3 tax years for limited liability companies and 4 tax years for cooperatives, limited partnership, and firms. This PP-23 final income tax is included in income tax Article 4 paragraph 2 of the income tax law.

\subsection{COVID-19 Tax Incentive Regulation}

Incentives for taxpayers affected by the COVID-19 pandemic are regulated in Regulation of the Minister of Finance of the Republic of Indonesia Number 44/PMK.03/2020. Five forms of incentives that the government provides to taxpayers include income tax 21 borne by the government, final income tax for MSMEs borne by the government, and exemption from income tax 22 imports. Besides, the incentive to reduce instalments of income tax 25 by $30 \%$ and the preliminary return of value-added tax are low risk for taxpayers who submit tax return value-added tax overpayments of up to 5 billion rupiahs in restitution.

The government bears the MSMEs' final income tax incentives for taxpayers who have a gross turnover match with and based on PP-23 of 2018 and have a certificate following PMK-44. Taxpayers who receive the tax incentives are required to submit a final income tax realization report no later than the 20th of the following month. The income tax exemption incentives for taxpayers who have met the criteria of having a business field classification code following PMK- 44 are determined to be companies that facilitate import for export destinations. Those taxpayers have obtained permits related to bonded zones and have applied for a certificate of exemption.

\section{Method}

This is a qualitative research since it delves deeply into phenomena and describes these phenomena as findings. Qualitative descriptive research was used in this study to obtain information about the participation of MSME taxpayers in utilizing tax incentives affected by the COVID-19 pandemic and to see the effectiveness of this incentive from the informant's point of view. To explore this phenomenon, this research requires information from sources that explain a phenomenon. The informants in this study consisted of 2 people who were a tax consultant and an accountant at MSMEs. The two informants were chosen because they are both the peope who facilitate and receive tax incentives. The effectiveness of tax incentives in this study is viewed from the benefits provided to incentive recipients. As the recipients of tax incentives, they can assess how well the effectiveness of the incentive they receive. Interviews are used as a medium to gather information from informants regarding taxpayer participation in utilizing tax incentives affected by the COVID-19 pandemic. For research, the identity of the informants in this study is covered up. To reduce the subjectivity of the interview results, the researcher did three main things, they are:

1. Hiring some people to code the interview results.

2. Asking the informants to review the interview results, and 
3. Performing triangulation data with other data sources that available.

Table 1. List of informants

\begin{tabular}{ccc}
\hline No. & Informants & Profession \\
\hline 1 & Miss V & Tax Consultant \\
2 & Miss L & MSME Accountant \\
\hline
\end{tabular}

\section{Results}

Through interviews with the two informants, several points were obtained regarding the implementation of the COVID-19 tax incentive. These points are presented in the form of sub-sections to facilitate the delineation of the flow to coherently answer the objectives of this study.

\subsection{MSMEs Tax Obligation}

As previously explained in the introduction, general and specific tax obligations (incentive recipients) are fundamentally different. Taxpayers in normal activities are required to do calculations, deposit, and report. In contrast, taxpayers who receive tax incentives only need to calculate the incentives and report the government's taxes. MSMEs taxpayers who get tax incentives must have a certificate issued by the Directorate General of Taxes. This certificate is an absolute must-have for taxpayers, especially MSMEs, as a basis for receiving tax incentives. The certificate is issued directly by the tax authorities through the website of the Directorate General of Taxes. Taxpayers only need to download the certificate on the respective website through the e-reporting submenu. As said by Miss L who explained:

For the letter, it's easy, Bro. Just log in to Directorate General of Taxes website, then enter the e-reporting menu. Now there will be some window (notification) to us whether we get tax facilities that are borne by the government or not. The letter will automatically appear, Bro, if our company is included in the category and we can save it and not have to worry because it can be printed repeatedly.

Tax consultant $\mathrm{V}$ conveyed the same thing regarding the taxpayer's obligation to have a certificate as a requirement for tax incentive recipients. This certificate can be the basis if at any time there is a request for data or an examination from the tax office regarding taxpayer compliance:

The taxpayer must actually have the certificate as the basis for the MSMEs receiving facilities from the Directorate General of Taxes. The letter will appear automatically on the taxpayers' dashboard. The letter is filed so that if one day there is a clarification from the tax authorities, we can explain that the taxpayer gets the final income tax facility borne by the government, especially during the incentive period.

After the taxpayer gets the certificate of incentive recipient, the next tax obligation is to calculate the income tax borne by the government. The basis for calculating the government's income tax is by multiplying the MSME tax rate by the turnover each month. The rates used are in accordance with the rates stipulated in Government Regulation Number 23 of 2018 of $0.5 \%$. Tax consultant V explains:

For the calculations, it is effortless, Bro, the taxpayer needs to convey the turnover. How much will it be multiplied by the final MSME income tax rate? Now the multiplication result is the amount borne by the government. Then the taxpayer will fill in the tax-borne tax report form. 
The form generally contains information on the turnover in a month and taxes borne by the state.

Documents commonly used by taxpayers to present the results of tax calculations are using a tax return. For documents used by incentive recipient taxpayers, namely a form in the form of Microsoft Excel, which contains information on turnover and taxes borne by the government.

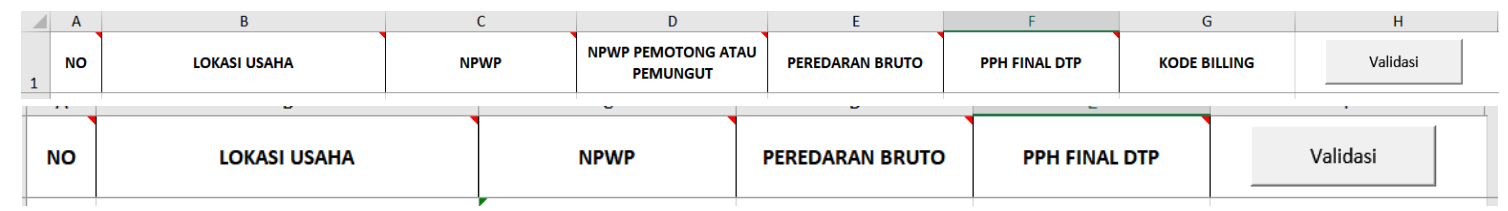

Figure 1. MSMEs taxpayer special tax incentive reporting form

Figure 1 exhibits that taxpayers are asked to present the gross turnover of each month and calculate the tax that must be borne by the government, which is $0.5 \%$ of turnover. If the taxpayer trades with taxcutters/tax-collectors, the taxpayer needs to convey the party that made the withholding or the collection. In addition, taxpayers are required to present the billing code for the transaction withheld/collected. The last activity carried out by the MSME taxpayers who receive tax incentives is to report the filling in the form on the Directorate General of Taxes website. This reporting is done every month at the maximum of the 20th after the tax period ends. As explained by tax consultant V:

If you look at the regulation, taxpayers are generally obliged to submit tax borne by the government online. It looks like the website is still on Directorate General of Taxes website, but there is a separate submenu. The report is the same as when reporting, and taxpayers are only required to upload documents. The excel document is validated first and then uploaded on the DGT website. It's easy, Bro. You just have to upload it. The most important thing is the calculation is there, of course in the format and upload the document, that's all.

The provision of tax incentives to MSME businesses is valid from April 2020 to December 2020. This tax incentive is expected to ease the financial burden on MSMEs affected by the COVID-19 pandemic.

\subsection{Current Condition of MSMEs}

Lots of companies have experienced negative impacts due to COVID-19 pandemic. Some of the general impacts, in general, are a decline in the business climate due to the low purchasing power of the people and existing layoffs everywhere. MSMEs also experience the same thing. According to the tax consultant Miss V, all of her clients experienced a decrease in turnover of around $40 \%-60 \%$. This will certainly be burdensome for MSMEs, especially to pay for operating expenses and tax burdens. From the start, the final rate for MSMEs has decreased to $0.5 \%$, but if there is a decrease in turnover by $50 \%$ to $60 \%$ and MSMEs still have to pay taxes, of course, this won't be very easy for the finances of the MSMEs and can have an impact on the rolling of the MSMEs. In addition to the condition of decreased turnover, according to Miss V, several clients should have an advantage over the occurrence of COVID19 and they can reap benefits in this condition because of the nature of the operation. However, in reality, this company still does not reap the profits that were initially assumed.

The main reason for this is the intense competition, and Miss V's clients are unable to take advantage of the competitive advantage they had during the COVID-19 pandemic. The extreme decline in 
Indonesia's economic conditions has prompted the government to step in by providing various tax incentives during COVID-19. These tax incentives have undergone several changes in practice. One of these incentives was launched to MSMEs to ease their financial burden so that the financial impact decreased to minus and employee layoffs could be mitigated. The question is how the effectiveness of this policy for MSMEs. Do MSMEs get the benefits estimated by the government? Has this policy's launch been effective in stemming the negative impact of COVID-19 on the business and economic sectors, especially for MSMEs that have relatively lower liquidity and capital than large companies?

\subsection{Effectiveness of the COVID-19 Tax Incentive}

It is known from Miss V's statement that there were many of her clients have applied for the COVID19 tax incentives, and most of their submissions were accepted because their clients met the criteria for this incentive object. The quantity of incentives submitted does not simply indicate the quality of this policy. The effectiveness of the COVID-19 tax incentives remains questionable. This is because there are still many MSME taxpayers who have not taken advantage of this tax incentive even after 5 months of the issuance of this program (pajak.go.id). Although some have proposed this tax incentive, the form is more of an escape so that the losses suffered are not too large. Only 9\% or 200,000 of around 2.3 million MSMEs take the tax incentives opportunity. This incentive is a subsidy and is not a cure for the economic downturn in Indonesia. According to Miss L, an MSME accountant affected by COVID-19 whose MSME fulfils the criteria for submitting incentives and successfully receives COVID-19 tax incentives, this policy can slightly reduce the financial burden that must be borne by the MSMEs where she works. On the other hand, Miss L also hopes that the incentive is increased or a new, more efficient scheme could be made.

Miss $\mathrm{V}$ stated that the tax incentive scheme related to reducing the income tax rate 25 was less effective for MSMEs, especially those with a large value-added tax. Because most of the formers of the MSME tax burden arising from value-added tax, not from other income tax types. Miss $V$ hopes that the government can implement a scheme related to value-added tax reduction to reduce its clients' burden. This scheme will be very impactful and efficient from the MSMEs side to ease their financial burden further. Besides, the income tax 21 reduction scheme is also a little less helpful in terms of MSMEs. According to Miss V, income tax 21 is responsible for the employees themselves, so the implementation of this scheme does not help MSMEs but can help MSME employees. The COVID-19 tax incentive policy still has many questions, especially regarding the sustainability of the COVID-19 tax incentive itself. The tax incentive for MSMEs is quite effective even though it has less impact because the largest tax burden from an MSME does not come from business circulation but comes from transactions related to value-added tax.

\subsection{COVID-19 Tax Incentive COVID-19 Tax Incentives: Relief or Burden?}

Miss V's and Miss L's confessions show that the COVID-19 tax incentive can indeed help MSMEs who are experiencing financial difficulties amidst the pandemic. However, there are questions in both informants' minds regarding the government's ability to implement this policy. You say this policy is a double-edged sword. First, the sustainability of this policy is questioned. Why? Because government's funding sources are limited, while the number of MSMEs is vast. If the government carries out this policy in the long term, it will have implications for two things; First, the government's financial burden will be even greater because it bears MSME tax incentives and second, tax-related state revenues are reduced due to a reduction in import taxes. Then the funds used by the government to carry out state operations and finance infrastructure will also decrease. 
If this incentive lasts for a long time, it will be very degradative for the government, especially because nobody knows when this COVID-19 pandemic will end. On one side, this will certainly ease MSMEs, but on the other side, it will burden the state finances, which are currently supported by foreign debt. In this case, the government needs to determine other policies that can still help alleviate the community and companies and not too burdensome to the government. The government can simulate calculations related to the cost and benefit of a policy. This simulation can include several alternatives, and the calculation of the simulation can use an econometric model to formulate the best incentives as described in Lin and Zeng's (2017) paper.

After the government determines the best alternative incentive scheme, this incentive scheme can be made so that its policies have high alignment and low complexity. This refers to the scientific article by Morrow and Rupert (2015), highlighting that taxpayers tend to take advantage of a tax incentive if the tax incentive has high conformity and low filing complexity. This policy can also be made to minimize unwanted results, such as the emergence of opportunities for tax evasion and tax avoidance, as well as inappropriate incentive targets (OECD, 2012). For this reason, as a supplement, before the government implementing policy needs to practice reasonable management elements in making an incentive that refers to the OECD (2012), namely transparency, accountability, monitoring and evaluation. This can be achieved by having budget documents, incorporating incentive provisions into tax laws/regulations, clearly defined eligibility criteria, tax officers' capacity to manage incentive programs, gathering information that allows monitoring and evaluation, and so on.

\section{Conclusions}

During the COVID-19 pandemic, the Indonesian Government issued policies related to COVID-19 tax incentives, which aim to ease the financial burden on MSMEs so that these MSMEs will not go out of business. Through the results of interviews with parties whose work are intersecting with COVID-19 tax incentives, it is found that the incentive schemes offered by the government are still ineffective. This is due to the low number of MSMEs that use this facility. Moreover, although tax incentives provide great benefits to reduce the financial burden of MSMEs during the pandemic, the amount of tax incentives provided is still considered insufficient when viewed from the losses experienced by MSMEs during the Covid-19 pandemic. However, MSMEs that meet the requirements can still apply for the COVID-19 tax incentives to reduce their financial burdens. It is expected that the government can further develop incentive schemes that are more useful in reducing the burden borne by MSMEs with low liquidity and low resistance during this pandemic such as tax incentive for value-added tax.

The informant, a tax consultant, also highlighted that the incentive for COVID-19 still covers taxes that tend to have low significance when viewed from the side of MSME expenditures, so that the relief effect provided is still lacking. Tax incentives in the form of a reduction in value-added tax are deemed to be more effective in reducing the burden on MSME taxpayers, referring to an informant's opinion. The same informant also highlighted whether there were no incentives for large companies during this pandemic. The current COVID-19 incentive scheme still has several gaps for improvement. However, given the limited government funds and Indonesia's low level of solvency, at this point, the government needs to make improvements to COVID-19 tax incentives, both in terms of schemes, policies and systems.

The government must also take into account the costs and benefits of implementing this tax incentive. This is because the amount of funds borne and lost from the government's hands is quite a lot, especially the tax funds. The government can reformulate incentive schemes that are more profitable for both the government and MSMEs so that no party is biased and tends to be deprived in implementing this policy. 
The government can use Lin and Zeng's (2017) econometric model as a reference to formulate a new, better tax incentive scheme.

This study's results need to be taken with caution because of the limitations inherent in this paper. First, the results of this study have low coverage, so that they cannot be generalized. It is necessary to carry out further studies on several other objects to increase the generalizability of the research findings and confirm whether the phenomena that occur in the object of research also occur in other objects outside of this research. Second, this paper only focuses on the taxpayers' point of view who take advantage of the COVID-19 tax incentives. Future research can also include the point of view of policymakers or policy implementers, for example, the Directorate General of Taxes.

\section{References}

Daude, C., Gutierrez, H., \& Melguizo, A. (2017). Doctoring the ball: The political economy of tax incentives for investment in the Dominican Republic. Journal of Economic Studies, 44(1), 2-23. https://doi.org/10.1108/JES-05-2015-0090

Directorate General of Taxes. (2021). Looking at Tax Incentives for MSMEs from a Contagious Perspective. Retrieved from https://www.pajak.go.id/id/artikel/melihat-insentif-pajak-bagi-umkmdari-perspektif-contagius

Jose, M., Sharma, R., \& Dhanora, M. (2020). R\&D tax incentive scheme and in-house R\&D expenditure: evidences from Indian firms. Journal of Advances in Management Research, 17(3), 333-349. https://doi.org/10.1108/JAMR-05-2019-0080

Kompas Pedia Kompas. (2020). Portrait and Challenges of MSMEs in Indonesia. Retrieved from https://kompaspedia.kompas.id/baca/paparan-topik/potret-dan-tantangan-umkm-di-indonesia

Lin, H.-c., \& Zeng, T. (2017). Information asymmetry and incentive contracting with the tax department. Review of Accounting and Finance, 16(3), 385-402. https://doi.org/10.1108/RAF-04-2016-0063

Manly, T.S., Thomas, D.W., \& Schulman, C.T. (2006). Tax Incentives for Economic Growth: Capital Investment or Research. Luttman, S. (Ed.). Advances in Taxation, 17, 95-120. https://doi.org/10.1016/S1058-7497(06)17004-0

Morrow, M.L., \& Rupert, T.J. (2015). The Effect of Federal-State Conformity on Taxpayer Decisions. Advances in Taxation, 22, 37-73. https://doi.org/10.1108/S1058-749720150000022001

Organisation for Economic Co-operation and Development (OECD). (2000). A Sample Survey and Analysis of Corporate Tax Incentives for FDI. Prepared for the November 8-9, 2000 Conference on OECD, South East Europe.

Organisation for Economic Co-operation and Development (OECD). (2008). Tax incentives for investment: A global perspective experiences in MENA and Non-MENA countries. In Making reforms succeed: moving forward with the MENA investment policy agenda. OECD, Paris.

Organisation for Economic Co-operation and Development (OECD). (2010). R\&D Tax Incentives: Rationale, Design, Evaluation.

Organisation for Economic Co-operation and Development (OECD). (2012). Perspectives on tax incentives for investment. In Task Force on Tax and Development Sub-group on State-building, Taxation and Aid. OECD. 
Organisation for Economic Co-operation and Development (OECD). (2018). Tax Incentives in Mining: Minimising Risks to Revenue. In Intergovernmental Forum on Mining, Minerals, Metals and Sustainable Development. OECD, Canada.

Organisation for Economic Co-operation and Development (OECD). (2020). Tax and Fiscal Policy in Response to the Coronavirus Crisis: Strengthening Confidence and Resilience. OECD.

Roca, J. (2010). Evaluation of the Effectiveness and Efficiency of Tax Benefits. Discussion Paper of Inter-American Development Bank.

Van Wyk, E. (2010). Tax incentives for biodiversity conservation in the Western Cape. Meditari Accountancy Research, 18(1), 58-75. https://doi.org/10.1108/10222529201000005

Analisis Partisipasi Wajib Pajak Usaha Mikro, Kecil, dan Menengah (UMKM) dalam Memanfaatkan Insentif Perpajakan yang Terkena Dampak Pandemi COVID-19

\begin{abstract}
Abstrak
Kajian ini bertujuan untuk menilai efektivitas insentif pajak COVID-19 yang telah dikeluarkan pemerintah. Berfokus pada wajib pajak Usaha Mikro, Kecil, dan Menengah (UMKM) untuk berpartisipasi dalam insentif pajak COVID-19. Dengan menggunakan metode kualitatif, penelitian ini melakukan wawancara mendalam dengan 2 informan yang merupakan konsultan pajak dan akuntan UKM. Hasil penelitian menunjukkan bahwa efektivitas insentif pajak COVID-19 masih kurang, hal ini sejalan dengan masih rendahnya partisipasi UMKM dalam memanfaatkan insentif perpajakan. Rendahnya partisipasi UMKM dalam memanfaatkan insentif pajak terlihat dari data yang menunjukkan bahwa setelah 5 bulan menjalankan program, dari sekitar 2,3 juta UMKM, baru 200.000 yang memanfaatkan fasilitas ini. Konsultan pajak menyatakan bahwa skema yang telah dilaksanakan adalah memitigasi beban keuangan UMKM yang tidak efektif karena objek insentif tidak substansial. Informan juga menyarankan insentif untuk menutupi pajak pertambahan nilai. Pemerintah diharapkan dapat menciptakan skema insentif yang baru dan lebih baik. Skema insentif baru juga untuk memberikan keseimbangan tanggung jawab baik bagi pemerintah maupun masyarakat. Makalah ini berkontribusi secara teoritis dengan mengkaji jenis baru insentif pajak, yaitu insentif pajak COVID-19, dan membantu pembuat kebijakan membuat skema insentif pajak yang lebih baik di masa depan.
\end{abstract}

Kata kunci: COVID-19, insentif pajak, UMKM 